\title{
APPROACHES TO THE DEVELOPMENT OF A LITERARY TRANSLATOR'S LINGUISTIC IDENTITY
}

\author{
Michael M. Naydan \\ The Pennsylvania State University, University Park, USA \\ mmn3@psu.edu \\ Mariia Ivanytska \\ Taras Shevchenko National University of Kyiv, Kyiv, Ukraine \\ ivanytska@ukr.net \\ Alla Perminova \\ Taras Shevchenko National University of Kyiv, Kyiv, Ukraine \\ alla.perminova777@gmail.com
}

\begin{abstract}
The article discusses the development of the linguistic identity of a novice literary translator in the course of academic training. The authors claim that teaching literary translation presupposes creating an academic environment conducive to untapping the creative potential of translation students. The paper describes an experiment in which 30 Ukrainian translations of the prologue from Julia Franck's novel "Die Mittagsfrau" executed by young translators were analysed. The outcomes of the research allowed for the identification of translation strategies and typical translation mistakes, and the dependence of translations on the translator's linguistic identity. The study proves the hypothesis that creativity comprises an indispensable component of the translator's personal linguistic identity and can be developed in the course of professional training. This also allows the authors to highlight the factors that influence the formation of the translator's professional competence as well as outline perspectives for further research into thinkaloud protocols provided both by experienced and novice translators.
\end{abstract}

Keywords: linguistic identity; novice translator; literary translator; creative approach; creativity; translator competence; strategy.

\section{Introduction}

Due to the incessantly growing market for translated literature, the issues of the quality of literary translation (House, 2001, pp. 197-200) along with the nurturing of a new generation of professionals who can meet the readership's demand efficiently are becoming more and more relevant. Despite Venuti's (1995) well-known statement about the translator's invisibility, we argue that a reasonable degree of creative visibility is expected from the translator of literary texts. We also assert that creativity lies at the core of the translator's linguistic identity, the creation of an environment conducive to the formation and development of which should be one of the top priorities of schools of higher education in preparing literary translation specialists.

A creative approach is an integral part of the literary translator's professional competence. It implies the ability to move away from a conventional understanding of textual units and to reassess them in the broader context of a global picture. This suggests the need for obligatory changes of the source text (ST) units, necessitated by semantic and syntactic discrepancies between the source and target languages (SL, TL), as well as for adaptation of the target text (TT) to the linguistic and cultural norms of the TL. A creative translator consciously chooses in favour of losses, provided they are justified by the aim to create a pragmatic effect commensurate with that of the original.

Both Ukrainian and foreign scholars have developed methods that enable educators to take a deeper look into the very process of the birth of creative translation and consequently improve approaches to literary translators' training (Vienne, 1994, pp. 51-59). Psycholinguistic methods have been successfully implemented by a Ukrainian Translation Studies scholar Rebrii (2012), which allowed him to discuss such issues as constraints to creativity in translation, to highlight systemic and creative aspects of translation, and ultimately to posit the theory of a translator's creativity, as well as lingual, textual and activity-related dimensions. Gile's integrated problem and decision reporting method encourages students to report on their reflections on specific translation challenges, which contributes to the elaboration of a conscious approach and teaches them to analyse translation decisions, gradually departing from linear translation to non-linear (Gile, 2004, pp. 6-10). The creative approach is typically characterised as divergent (Guilford, 1975, pp. 3759) or lateral (De Bono, 1971, p. 42), because instead of following a linear sequence, the translator

Naydan, M., Ivanytska M., \& Perminova, A. (2019). Approaches to the development of a literary translator's linguistic identity. Advanced Education, 12, 28-34. DOI: 10.20535/2410-8286.154389 
reasonably embraces various possibilities. De Bono (1971) emphasises that the ability to see several different alternatives is a sign of creativity (p.71). According to Kussmaul (2007), a creative translator is able to change perspective and look at the original and its fragments from a new angle, to see the connection between different categories and metaphorically or metonymically to recreate it (pp. 106-126). However, the author argues that such abilities are not something supernatural, but rather innate, and are used in other situations (Kussmaul, 2007, p. 126). This allows us to make a hypothesis that creativity as an indispensable component of the translator's linguistic identity can be developed by means of professional training. Our hypothesis is in line with Gerrit Bayer-Hohenwarter's findings stemming from a study of cognitive procedures in the course of consensual and prototypical creativity development in novice translators (BayerHohenwarter, 2009, pp.39-59). However, our study tackles the issue of creativity from the vantage point of the translator's linguistic identity. The few scholars who have done research in this area include Mazur (2011), who discusses the creative personality of a translator in various contexts and Bidna (2010), who focuses on the manifestations of linguistic identity in the reproduction of the poetic features of the original. Apart from that, the question of the development of the linguistic identity of a novice translator still remains. Therefore, this paper is aimed at the analysis of a number of translations of a single literary work executed by novice translators; the identification of translation strategies and typical translation mistakes; and dependence on the translator's linguistic identity. This will also allow for the identification of the factors that influence the formation of the translator's professional competence.

\section{Method}

Teaching literary translation as a professional activity necessitates a paradigm shift in the training methodology of a translator that is grounded in approaches different from ones that have proven their efficacy in the realm of foreign/second-language instruction. Using activities on translation in the course of foreign language teaching, especially at the lower levels, is generally oriented towards maximum conformity of the TT to the ST, even to the detriment of the naturalness of its resonance in the TL and the pragmatics of the utterance. However, literary translation implies the use of other, non-linear approaches. Sure enough, the transition of the novice translator's mind to the creative perception of the text of the original may impede or not even occur due to the acquired skill to translate accurately and closely to the original text. The imposed external censorship on the part of the teacher of a foreign language is internalised when novice translators themselves start controlling the proximity of the TT to the ST, and, as a result of critical evaluation, novice translators tend to discard more creative interpretations of original fragments, which often leads to substantial losses in terms of artistic merits.

Teaching literary translation presupposes creating an academic environment conducive to untapping the creative potential of students. This implies engaging students in stimulating activities, in which they are encouraged to exercise their freedom as creative personalities by solving a variety of translation tasks associated with conveying the artistic value of the original to the TT reader. The most effective activities comprise the assignments in which the students are asked to furnish solutions that do not pre-exist (translating poetry and poetic prose, rendering culturally biased units, puns, phonetically and semantically motived units - any kind of SL material that transcends the boundaries of ordinary usage and defies the TL reader's expectations). The awareness of the core literary translation maxim - translation is a creative process - as well as substantial exposure to practical experience, make the novice translators' mental processes more flexible and nonconventional. Students acquire the ability to cast the shackles of literalness in order to convey the meaning of the whole and transmit the "invisible" by means of TL.

With these ideas in mind we performed an experiment that involved the following operational components:

\section{Participants}

The experiment involved 30 novice translators with various academic backgrounds. The largest part of them were graduate (10) and undergraduate (15) students of Taras Shevchenko National University of Kyiv majoring in German philology and translation. Two participants had already graduated from the university with an MA degree in philology, and three young professionals without a philological background. We involved the latter group in the experiment to find out the impact of professional training (as well as the absence thereof) on translation adequacy. Most of the participants indicated Ukrainian as their mother tongue, six - bilingual Ukrainian and Russian, and three - Russian, but all translated into Ukrainian. All of them had some experience in literary translation (both poetry and prose) and were willing to commit their professional life to this endeavour. An important prerequisite for choosing subjects for this study consisted of academic excellence and the desire to participate in the experiment. 


\section{Materials}

30 translations from German into Ukrainian were analysed. The participants were instructed to translate the prologue of the novel by contemporary German writer Julia Franck "Die Mittagsfrau", which had not been previously translated into Ukrainian. The novel won the 2007 German Book Prize and may be rightfully considered a psychogram of German history. The action takes place in the town of Stettin in 1945. After being raped by Russian soldiers in a bombed-out apartment, the mother of an eight-year-old boy takes her son to the train station to go to Berlin and then abandons him there. This intensely dramatic beginning of Julia Franck's novel appealed immediately to the participants and made them both professionally and emotionally engaged in the experiment.

\section{Procedure}

The participants received their assignment at the same time and were allotted two weeks to execute their translation. They were instructed to use any sources they considered appropriate as well as to exercise their creativity while making their texts interesting for the potential Ukrainian readership. The translations were subsequently collected, compared, analysed, and statistically generalised in terms of faithfulness to the original, translation strategies, and typical mistakes. The most prominent findings of the analysis follow.

\section{Results and Discussion}

\section{Challenges. The Title}

Even though a book is not judged by its cover it certainly is by its title. Authors use various techniques for catching the potential readers' attention, letting them have certain expectations and then page by page either by matching those expectations or by defying them. Therefore, translating the title of a literary work is a truly strategic endeavour that requires holistic thinking and is often postponed till the end of the project when the entire book has been translated. Since the participants of our experiment were given only the introductory part of Franck's novel, they did not have an opportunity to consider the original in its entirety. However, one of the indispensable components of a translator's competence is professional intuition, which stems from academic training, real-life experience and encyclopaedic knowledge. Hence the analysis of the target language versions of the source's title allows us to trace certain strategies favoured by various translators. The participants were encouraged to use any sources of information available to help them translate adequately. It did not take them long to find out that the Mittagsfrau is an East German folklore figure, who would appear during the midday heat and steal the children of peasants at harvest time along with their sanity. She was known to be particularly relentless with those who would chat instead of work. However, according to legend, the magical power of the Mittagsfrau could be diminished if someone managed to have a conversation with her, especially on topics related to field work.

The title implies the author's intent to relate intertwined stories of people's lives in the palimpsest of German history. Thus, 16 participants resorted to a Ukrainian mythological equivalent of the culturallybiased German name "Mittagsfrau" - "Полудниия", whereas 3 entitled their works as "Полуденниия", the sound of which is more justifiable for a modern reader unfamiliar with folklore. This choice is endowed with an inner form, but at the same time, it may also hint at a symbolic meaning. 8 participants used loan translations such as "Полуднева (3) / Полуденна (3) жінка" or even "Полуднева пані" (2), this way decompressing the SL unit in an explanatory move, but losing its symbolic meaning. The same applies to the intriguing title "Жінка, яка приходить ополудні", that on the one hand evokes readers' curiosity, but on the other - shifts the focus from the abstract level to, presumably, the image of the main character, which departs from the author's intent as openly stated by her in numerous interviews. Another translation solution - "Полуденна відьма" - adds excessive transparency to the symbolic image of the folklore figure along with a negative connotation, which is also a deviation from the author's intention. The title "Жінка, що приносить обід" used by one translator is completely erroneous.

Interestingly enough, the Ukrainian version of the title "Полуденна відьма" (literally "Midday Witch") is the choice of the participant practising poetry translation who has had some of her translations published. However, she does not have a philological background. "Жінка, яка приходить ополудні" is the title suggested by a participant with a certain amount of experience in literary translation and a philological background. "Жінка, що приносить обід" - is the misleading resolution of an inexperienced translator with an MA degree in philology. The title "Полуднева пані" was favoured by two novice translators from Lviv. One translator vacillated between "Пообідня жінка" and "Полуденна жінка", which testifies to his attempt to preserve the external facet of the original title at the expense of its internal one. In analysing the translations, we observe that novice translators do not always understand the idiosyncrasy of the author's idea or the depth of meaning of certain ST units. In their search for direct correspondences, they often find 
themselves in the pitfall of literality or superfluous decorativeness of expression. Another vivid tendency is a conscious inclination towards descriptive rendering at the core of which lies an explication strategy. Scholars in the field of psycholinguistics believe that explication of implicit information is one of the universals of translation (Zasekin, 2012, p.37). However, it is more justifiable when there is a need to explain connections between sentences or to extend elliptical structures.

\section{Stylistically Marked Lexical and Syntactic Units}

Let us consider the strategies chosen by novice translators when reproducing stylistically marked lexical and syntactic units. For our analysis, we have chosen sentences, in which the arrival of the train at the station and the jostling of the crowd for seats in the coach are described. "Arme ruderten. Füße traten, schlugen aus, und Ellenbogen boxten Schimpfen und Pfeifen". The short non-extended first sentence, the triple grammatical repetition, the verbal style, the nominative second sentence - all serve to create an atmosphere of lively movement, struggle, and impetuosity. Young translators assume different approaches to rendering lexical and syntactic characteristics of the original. Some of them try to recreate the atmosphere with an extended sentence as well as to add a touch of their own interpretation: "Кожен прокладав собі илях як міг: вимахував руками, тупотів ногами, штовхався ліктями. Лайка і свист." (the translator of "Полуденна пані") ㅇ "Люди розмахували руками, пробивалися крізь натовп і штовхали один одного ліктями. Лаялися, свистіли”, ог "Всі розмахували руками, наступали один одному на ноги, штурхалися й штовхалися ліктями. Всюди лайка і свист" (the translator of "Полуденна відьма").

Although translators try to stay within the scope of the author's stylistics (repetition of homogeneous members of the sentence), they fail to resist the temptation of adding the subject of action, making the description of movements more detailed, expanding the picture, etc., which ultimately results in an aberration of the original's rhythm. We have observed that about a half of the translators extended the first sentence from 8 words in the original (including the conjunction) to 16 (1 translator), 12 (4 translators), 11 (2 translators), 10 (5 translators), and 9 (1 translator). Nine Ukrainian versions had the same number of words, but due to the length of the verbs, especially in the past tense, the rhythm was not preserved, for example: "Руки веслували, ноги наступали, проштовхувалися, а лікті боксували”. The rhythm changes even more when the instrumental case is used: "Люди гребли руками, топтали ногами, відбивалися, проштовхувалися ліктями". Therefore, even a six-word version of the translation ("Руками розмахували, ногами наступали, ліктями штовхали. Сварки і свист") is not the most dynamic. Seven other translators omitted the conjunction and condensed the original to seven lexical units: "Руки гребли, ноги топтали, товкли, лікті розпихали. Прокльони і свист". The rhythm of the original, as well as the importance of the length of verbs, was partly grasped by the translator who had also worked some in the field of journalism, which can be demonstrated by the following version: "Змахи рук, тупанина, важкий крок, товкотнеча, гострі лікті. Лайка і свист", although perhaps "важкий крок" is not the best fit for the situation portrayed.

Substantivised verbs "Schimpfen und Pfeifen" were mostly converted into nouns "Лайка / сварки / прокльони / галас та свист" (19), and sometimes - into verbal nouns "Сперечання та свистіння" (3). Seven translators produced sentences with verbs in the third person plural "Сварилися /лаялися $i$ свистіли."

We strongly believe that the choice of a TT unit should be governed not as much by lexical equivalence, but rather by functional correspondence in terms of the similarity of the communicative effect of the ST's and TT's messages (Lewis, 1985, p.43). A non-extended first sentence followed by homogeneous predicates of the second sentence sounds much better than the reverse syntactical pattern. This testifies to the lack of a single translation strategy in the works of novice translators, as well as to an unrefined feeling of the author's style, and, accordingly, to the absence of the translators' own style.

\section{Proper Names}

The same applies to the approach to rendering proper names (Andrienko, 2016, pp.194-215). There are quite a few of them in the analysed passage: "Peter" (the boy in the centre of the narrative in the prologue), "Wilhelm", "Alice" (his parents), "Anklam", "Angermünde", "Frankfurt", "Stettin" (cities). In all translations but one, the boy is called "Петер", thus translators retained the local colouring of the proper name. However, when there was a need for the vocative case in Ukrainian, only 11 used the form "Пlemepe" to conform to Ukrainian grammatical norms, whereas the other 18 neglected the vocative case, presumably resorting to a foreignisation strategy. It is interesting to note that the majority of the translators who used vocative case are philologists born and raised in Western Ukraine, and the other 3 are from Kyiv with a solid philological background. One translator from Lviv made the narrator go by the diminutive form of the name "Петрик". This is a vivid example of domestication that may also be observed in the title suggested by the 
same translator "Полуденна пані", which testifies to the translator's (albeit irrelevant) consistency. A certain range of discrepancy is revealed while analysing the ways the translators dealt with the name of the main character - "Alice". 13 translators used an equivalent that is a transcription from English "Eлic"; 14 domesticated, referring to the woman as "Aліса"; in three TTs we came across more intrinsically German versions of the character's name - "Аліс" and "Алice".

Other proper names were transcribed - "Вільгельм", “Франкфурт”, “Анклам”, “Ангермюнде”. However, the translators used different inflexions when these proper names occurred in cases other than the nominative. Thus in 5 translations the train goes to "в Анклам (and Антермюнде)", in 13 to "до Анкламу", in 6 to "до Анклама", in 3 to "до Анкламу та Ангермюнд/y/a", in 2 - "на Анклам та Ангермюнде" and, finally, there is a variation "до Анклами та Ангермюнде" along with the philologically prudent win-win option "до міст Анклам та Андермюнде", which, however, does not sound natural in the communicative situation described in the original - a dialogue between a mother and her son. It is interesting to note that this option was used by a diligent third-year student who, apparently, had just learned this technique of rendering proper names in her translation seminars.

The name of the city with a German-Polish past "Stettin" is also reproduced in different ways: closer to the German version: "Штеттин"- 4, "Штеттін"-9, even "Щетін"-1; and closer to the Slavic one: “Щецин”-13, “Щецін”- 2, and “Щецен”- 1. All this testifies to certain flaws both in the language competence of young translators and in the quality of reference material used by them.

Yet, when it came to the names of more or less well-known cities, young translators predominantly succeeded in finding an equivalent. However, rendering the historical name of the small town of "Scheune" near "Stettin", which also coincides with a common name that means "pantry /granary", proved to be more challenging. Almost all participants made mistakes (although they must have felt that the logic in their translation was poor), and therefore arbitrarily replaced the lexical unit with whatever they considered more or less suitable. So, the original reads as follows: "Er dachte an die Bockwürstchen, Die die Dame in Scheune ausgerufen hatte, vielleicht gab es hier welche". In most of the translations, Peter thinks about sausages, about which a woman was shouting from a ham / shed, or which were sold by a lady in a pantry / barn / storehouse / inn / tavern, etc: "про які викрикувала (галасувала) жінка із шинку / в сараї", "якими торгувала пані в коморі”, "які продавала (розхвалювала) жінка у будиі / клуні / сховищі / амбарі / корчмі / кабаку / забігайлівиі / закусочній”, "про які кричала жінка зі стайні", “які жінка ховала у коморі". One translator resorts to unjustified domestication "він згадував перепічку, що про неї кричала жінка поруч з повіткою", and the other - to an unjustified foreignisation: "Він згадував жінку за лядою, щзо гучно гукала "Боквурсти! Боквурсти!" Only 6 translators were able to identify the lexical unit as a geographical name: 4 of them were close to the original's context: "Він думав про гарячі сардельки, на які галасливо припрошувала пані в Шойне” / "Він згадав сардельки, про які на станції Шойне вигукувала жінка". One translator even provided a footnote to explain the proper name: “якась жіночка в Шойне (нині: Гуменще, район Щецина)"

The occurrence of the analysed proper name in the same context as the names of the cities of "Anglemünde" and "Stettin" as well as the absence of an article before Scheune" - may be considered as the only prompts for the translators, suggesting a need for more thorough research. However, it is not easy to find any information on the town of "Scheune" on the Internet. The fifth translator managed to identify this lexical unit as a proper name but erroneously interpreted it as a district in Berlin: "Він думав про гарячі сардельки, які жіночка продавала у берлінському кварталі Шойне із на весь голос викриками: “Сардельки! Гарячі сардельки! Продаються гарячі сардельки!” The sixth translator, for some reason, decided that the lady was ordering something in the Scheune restaurant, which contradicts the logic of the story about refugees.

We wish to stress that by providing the above examples we do not mean to draw the readers' attention to the multitude and variety of the novice translators' decisions, but rather to the need for developing a comprehensive approach to translator training with a special emphasis on professional competence, which encompasses a near perfect knowledge of the foreign language (which is indispensable) and his or her native language, cultural awareness, as well as commitment to excellence in terms of research and self-education. The findings of our research are statistically generalised in Table 1.

Since all participants of the experiment were novice translators, the results of the analysis suggest that even the presence of one or two published translations in their record is not a decisive factor in the development of the translator's linguistic identity, although the relevant educational and practical experience accelerates the acquisition of professional competence. At the same time, we observe that the very fact of the existence of translated works (which may not necessarily be published) has a positive effect on the translator's self-esteem and professional confidence, and is conducive to a higher degree of creativity 
exercised while handling stylistically/culturally marked ST units, as well as the ones that do not render themselves to linear reconstruction by means of the TL. Such translators feel more comfortable departing from the original, sometimes to the detriment of the author's intent, which results in mistakes.

Table 1. Correlation of Translators' Decisions Within the Spectrum of Participants

\begin{tabular}{|c|c|c|c|c|}
\hline Participants & $\begin{array}{c}\text { BA } \\
\text { Students }\end{array}$ & $\begin{array}{c}\text { MA } \\
\text { Students }\end{array}$ & $\begin{array}{l}\text { Young professionals } \\
\text { with a philological } \\
\text { background }\end{array}$ & $\begin{array}{c}\text { Young professionals } \\
\text { without a } \\
\text { philological } \\
\text { background } \\
\end{array}$ \\
\hline 30 & 15 & 10 & 2 & 3 \\
\hline $\begin{array}{l}\text { Blatant mistakes, content } \\
\text { distortion }\end{array}$ & 8 & 5 & 1 & 1 \\
\hline $\begin{array}{ll}\text { Prevalent } & \text { additions } \\
\text { (explicitation) } & \end{array}$ & 11 & 7 & 2 & 2 \\
\hline Prevalent omissions & 4 & 3 & - & 1 \\
\hline $\begin{array}{l}\text { Prevalent foreignisation } \\
\text { author's style preservation }\end{array}$ & 9 & 7 & 1 & 2 \\
\hline Prevalent domestication & 8 & 7 & - & 1 \\
\hline Creative decisions & 7 & 8 & 1 & 2 \\
\hline
\end{tabular}

Other than occasional instances of misinterpretations, many lexical and grammatical drawbacks indicate Russian-language interference with the formation of the translators' linguistic identity. The greatest number of such errors were found in the works of the participants who indicated Russian as their native language but claimed that Ukrainian was their operational language. Thus, to make the TT sound natural the translator should think in the categories of the TL.

However, the main concern at this point is that many young translators do not perceive the text as discourse, for the adequate rendering of which they have to go beyond textual boundaries (Hassan, 2011, pp. 1-24). It seems that the concept of professional empathy - the ability to get into the author's shoes, to feel the situation and ultimately to produce contextual correspondences - is predominantly alien to novice translators. This is something we aim to improve in our teaching practice.

The best translations, which can be called nearly adequate, were performed by the MA students majoring in translation studies as well as by university graduates of the translation department - who were practising translators. This proves our hypothesis that literary translation can be taught, but only to those who have sufficient prerequisites for this: a rich vocabulary and fluency in both working languages, intercultural competence, and the desire to exercise and develop their creativity.

\section{Conclusions}

High-quality literary translation is characterised by a creative approach both to understanding the original and to re-creating it in the TL. Creativity can be developed and trained, and accordingly, literary translation can be successfully learned.

We believe that the formation of the linguistic identity of a translator is a complex process, which must be rooted in solid linguistic competence, especially with respect to the TL. The possible ways to achieve this include: expanding the vocabulary in both languages through reading and analysing texts, enhancing encyclopaedic knowledge while translating texts on various subjects, discussions of translation strategies and techniques, developing long-term memory, and engaging students in creative writing assignments in both languages.

Unfortunately, as it turned out, even the best translation majors still lack sufficient competence, which is required for the translator of fiction. The same can be said about translation competence. We believe that it is possible to improve the quality of literary translation and training of the younger generation of translators by reconsidering approaches to students' enrolment in MA programmes in Ukraine: admit applicants with very good command of the Ukrainian and a foreign language so that the training does not aim at mastering the language/languages, but rather at honing translation skills; at acquiring techniques that allow for overcoming cultural asymmetry and semantic lacunae; and at extending the student's professional portfolio of real literary translation projects. The latter has already been incorporated in the course of Translation Project Management, which has been taught successfully at Taras Shevchenko National University of Kyiv for three years. 
Just like any study, the experiment described in this article has certain limitations on which we hope to improve in our further research into the process of the formation of a translator's linguistic identity. One of the promising avenues of research would be a study into think-aloud protocols of novice and experienced literary translators.

\section{References:}

Andrienko, T. (2016). Strategii i taktyky perekladu: kognityvno-dyskursyvnyi aspekt (na materiali khudozhniogo perekladu $z$ angliyskoi movy na ukrainsku) [Strategies and tactics of translation: cognitive and discourse aspect (based on literary translation from English into Ukrainian)]. Kyiv: Vydavnychyi dim Dmytra Burago.

Bayer-Hohenwarter, G. (2009). Translational Creativity: How to Measure the Unmeasurable. In S. Gopferich et al. (Eds.), Behind the Mind: Methods, Models and Results in Translation Process Research (pp.39-59). Copenhagen: Samfundslitteratur.

Bidna, T. (2010). Proyavy movnoi osobystosti perekladacha pry vidtvorenni tropeichnyh zasobiv [Manifestations of the translator's linguistic identity while reproducing tropic means]. Naukovyi visnyk Khersonskogo derzhavnogo universytety, 10, $337-342$. Retrieved 15 December 2018 from http://linguistics.kspu.edu/

De Bono, E. (1971). Laterales Denken. Ein Kursus zur Erschließung Ihrer Kreativitätsreserven (M. Carroux\&W. Eisermann, Trans.). Reinbek bei Hamburg: Rowohlt.

Gile, D. (2004). Integrated Problem and Decision Reporting as a Translator Training Tool. The Journal of Specialised Translation, 2 , 6-10. Retrieved 15 December 2018 from https://www.jostrans.org/issue02/art_gile.php

Guilford, J.P. (1975). Creativity: A Quarter Century of Progress. In I. Taylor, and J. Getzels (Eds.), Perspectives in Creativity (pp. 37-59). Chicago, IL: Aldine Publishing Company.

Hassan, B.A. (2011). Literary Translation: Aspects of Pragmatic Meaning. Newcastle upon Tyne: Cambridge Scholars Publishing.

House, J. (2001). Quality of Translation. In Mona Baker et al. (Eds.), Routledge Encyclopedia of Translation Studies (pp.197-200). London\&New York: Routledge.

Kussmaul, P. (2007). Kreatives Übersetzen. Tübingen: Stauffenburg.

Lewis, Ph. (1985). The Measure of Translation Effect. In J.Graham (Ed.), Difference in Translation (pp.31-62). Ithaca\&London: Cornell University Press.

Mazur, O.V. (2011). Doslidzhennia tvorchoi osobystosti perekladacha u svitli teorii kontekstiv [A study into creative personality of a translator in light of the theory of contexts]. Naukovyi visnyk Volynskogo natsionalnogo universytetu imeni Lesi Ukrainky, $6(2), 65-71$.

Rebrii, O. (2012). Suchasni kontseptsii tvorchosti u perekladi [Modern concepts of creativity in translation]. Kharkiv: Kharkivskyi natsionalnyi universytet imeni V.N. Karazina.

Venuti, L. (1995). The Translator's Invisibility. London\&New York: Routledge.

Vienne, J. (1994). Towards a Pedagogy of "Translation in Situation". Perspectives: Studies in Translatology, 2(1), 51-59. https://doi.org/10.1080/0907676X.1994.9961222

Zasekin, S.V. (2012). Psykhologichni universalii perekladu khudozhniogo tekstu [Psychological universals of literary translation]. Lutsk: Volynskyi natsionalnyi universytet imeni Lesi Ukrainky. 